\title{
POWER OF GOVERNMENT OVER SPEECH AND PRESS
}

\author{
FRED. B. HART \\ Oakland, California
}

"The government of the United States is one of enumerated powers; the national Constitution being the instrument which specifies them, and in which the authority should be found for any power which the government assumes to possess." ${ }^{\text {It }}$ "can claim no powers which are not granted by the Constitution." If If, therefore, there is not an express grant of authority over the press and speech and if the enforcement or execution of any delegation does not require restriction or regulation on such subjects, then the federal government is without power in the premises.

As originally ratified, prior to the adoption of the first ten Amendments, the Constitution contained no reference to the press or freedom of speech. In the Convention of 1787 , the advisability of incorporating a provision on the subject was considered, and after due deliberation the delegates decided to omit it as unnecessary and likely to raise complications and uncertainty. In Elliott's Debates, ${ }^{3}$ we find the following. references to the subject.

"Friday, September I4, Mr. Pinckney and Mr. Gerry moved to insert a declaration 'that the liberty of the press be inviolably preserved.'

"Mr. Sherman: 'It is unnecessary. The power of Congress does not extend to the press.'

"On this motion it passel in the negative."

"In the debate on the constitution in the South Carolina Convention, Gen. Lincoln referred to the absence of such a provision, saying, 'The liberty of the press is the tyrant's scourge; it is the true friend and supremest supporter of civil liberty. Therefore why pass it by in silence.' He was immediately answered by Gen. Pinckney [the very man who in the Federal Convention moved such a clause but whose motion was rejected]. Gen. Pinckney said 'With regard to the liberty of the press, the discussion of that subject was not forgotten by the members of the convention. It was fully debated and the impropriety of saying anything about it clearly evinced. The General Government has no powers but what are expressly granted to it; it therefore has no power to take away the liberty of the press.

\footnotetext{
${ }^{1}$ Cooley, Constitutional Limitations (7th ed. I903) Ir.

${ }^{2}$ Martin v. Hunter's Lessees (1816, U. S.) I Wheat. 304, 326. [See also, developing this thought, the article by W. F. Dodd, Implied Powers and Implied Limitations in Constitutional LazU (1919) 29 Yale LAw JournaL, 137.-ED.]

${ }_{5}^{5}$ Elliot's Debates (Philadelphia, Igor) 545 .
} 
That inviolable blessing which deserves all the encomiums the gentleman has justly bestowed upon it, is secured by all our State constitutions; and to have mentioned it in our general constitution would perhaps furnish an argument hereafter that the General Government had a right to exercise powers not delegated to it.'"

The same subject is referred to by Alexander Hamilton in THE FEDERAList, and by James Madison in his famous Report on the Virginia Resolutions.

At that time there were in this country two distinct schools of political thought, holding opposing beliefs as to and concerning government. There were few questions on which they agreed. It is significant when we find them in accord on any subject. The party of which Alexander Hamilton was a conspicuous leader believed that under the original constitution, the federal government had no power to regulate or legislate as to the freedom of the press and of speech. The party with which Thomas Jefferson affiliated contended no less vigorously that such authority was not delegated by that instrument, but insisted that creation of such power by construction might be attempted. The question arose, therefore, as to the advisability of incorporating a prohibition in the Constitution.

Hamilton said:

"I go further, and affirm, that bills of rights, in the sense and to the extent in which they are contended for, are not only unnecessary in the proposed Constitution, but would even be dangerous. They would contain various exceptions to powers not granted; and on this very account, would afford a colourable pretext to claim more than were granted. For why declare that things shall not be done, which there is no power to do? Why, for instance, should it be said, that the liberty of the press shall not be restrained, when no power is given by which restrictions may be imposed? I will not contend that such a provision would confer a regulating power; but it is evident that it would furnish, to men disposed to usurp, a plausible pretence for claiming that power. They might urge with a semblance of reason, that the constitution ought not to be charged with the absurdity of providing against the abuse of ar authority which was not given, and that the provisions against restraining the liberty of the press afforded a clear implication, that a power to prescribe proper regulations concerning it, was intended to be vested in the national government."

Hamilton thus feared that if we adopted such an amendment, it might afford groundwork for a "pretense" to regulate and that "men disposed to usurp" might make a colorable though false argument in favor of such power. He was afraid of the opportunist, the man of intellectual dishonesty, not of logic or sound disputation; afraid of the effect that such an amendment might have upon minds unduly influenced by the excitement of the moment. ${ }^{5}$

\footnotetext{
‘The Federalist (ed. J. C. Hamilton, 1864) 631.
}

"Ibid. 
Jefferson said, in answer to the suggestion and argument of Hamilton:

"Very well, I agree with you that the power is not legitimately here, and that it was not intended to be here, and that it is a subject matter which belongs to the States, the same as the common police power of the States. But there is in the Constitution a provision that Congress shall have power to pass all laws necessary for the purpose of carrying into effect the powers here granted, and it might be held and construed to include regulation and legislation concerning the press. Therefore, accepting your view that it is not among such powers, we ask for a declaratory amendment to the Constitution which shall put it beyond peradventure that it is not one of the powers granted to the National government."

Both agreed that no power over the press and speech had been delegated. But in order to remove all possibility of doubt and render impossible a decision that any restraint shall be put on the right as a means of execution of an express power, the First Amendment was adopted. It was adopted, not to curtail authority, but as "a declaratory amendment," and that, too, in words whose mandatory purport can admit of no manner of doubt.

Jefferson believed that the right of a free press and of liberty of speech was of paramount importance to the very existence of free institutions. He says that "the liberty of speaking and writing guards our other liberties"; "to punish these errors too severely would be to suppress the only safeguard of the public liberty"; "our liberty depends on the freedom of the press, and that cannot be limited without being lost." Of Jefferson's service in procuring this Amendment, it is said by one now prominent in affairs of State, in an article in Volume I6 of Jefferson's Works:

- Josephus Daniels, in 18 The Writings of Thomas Jefferson (Washington, 1904) x, xi. Cf. also James Madison's Report to the Legislature of Virginia:

"When the Constitution was under the discussions which preceded its ratification, it is well known that great apprehensions were expressed by many lest the omission of some positive exception from the powers delegated of certain rights and of the freedom of the press particularly, might expose them to danger of being drawn by construction within some of the powers vested in Congress, more especially of the powers to make all laws necessary and proper for carrying their other powers into execution. In reply to this objection it was invariably urged to be a fundamental and characteristic principle of the Constitution that all powers not given by it were reserved; that no powers were given beyond those enumerated in the Constitution, and such as were fairly incident to them; that the power over the rights in question and particularly over the press was neither among the enumerated powers nor incident to any of them, and consequently that any exercise of such power would be manifest usurpation. It is painful to remark how much the arguments now employed in behalf of the sedition act are at variance with the reasoning which then justified the constitution and invited its ratification. . . . Without tracing further the evidence on this subject, it would seem scarcely possible to doubt that no power whatever over the press was supposed to be delegated by the Constitution as it originally stood and that the amendment was intended as a positive and absolute reservation of it. But the evidence is still stronger. The proposition of the amendments made by Congress is introduced in the following terms: "The conventions of a number of States having at the time of 
"For this Amendment and the healthy agitation that secured it, all men who believe in a free press will ever hold Jefferson in grateful esteem. It was contended that this amendment was wholly unnecessary-'useless surplusage,' as one Federalist declared-but the prophetic eye of the liberty-loving sage of Montecello looked from Paris across the Atlantic and saw that the influences that distrusted the people would muzzle the press unless the constitution forged chains that would deny power 'abridging the freedom of speech or of the press." "

The people having designedly determined the extent of the delegation of power and not having granted any over the press or speech, the conclusion is inevitable that the founders of this government, of every faction and of every school of political thought, intended that no authority whatsoever over the press or speech, even though it be in aid of an express power granted, should be possessed by the government they created. It is not a question of what powers should have been granted, but as to whether they were in fact delegated. And the language of the First Amendment is express and clear: "Congress shall make no law . . . abridging the freedom of speech or of the press" - a clear, absolute, positive prohibition-not in relation to regulation, but in regard to any law whatsoever.

It has been asserted that such power is implied in that provision of the Constitution defining treason and in that providing for the so-called war power.

What is the effect of these provisions? Do they extend the power of government and give control over speech and press? Is there not

their adopting the Constitution expressed a desire in order to prevent misconstructions and abuse of its powers, that further declaratory and restrictive clauses should be added; and as extending the ground of public confidence in the Government will best insure the beneficent ends of its institutions.' Here is the most satisfactory and authentic proof that the several amendments proposed were to be considered as either declaratory or restrictive, and whether the one or the other, as corresponding with the desire expressed by a number of the States and as extending the ground of public confidence in the Government.

"Under any other construction of the amendment relating to the press than that it declared the press to be wholly exempt from the power of Congress the amendment could neither be said to correspond with the desire exprcssed by a number of the States nor be calculated to extend the ground of public confidence in the Government.

"Nay, more, the construction employed to justify the 'sedition act' would exhibit a phenomenon without parallel in the political world. It would exhibit a number of respectable States as denying, first. that any power over the press was delegated by the Constitution; as proposing, next, an amendment to it should explicitly declare that no such power, was delegated, and, finally, as concurring in an amendment actually recognizing or delegating such a power.

"Is, then, the Federal Government, it will be asked, destitute of every authority for restricting the licentiousness of the press and for shielding itself against the libelous attacks which may be made on those who administer it?

"The Constitution alone can answer the question. If no such power be expressly delegated, and if it be not both necessary and proper to carry into execution an express power; above all, if it be expressly forbidden by a declaratory amendment to the Constitution, the answer must be that the Federal Government is destitute of all such authority." Elliott, The Virginia and Kentucky Resolutions of 1798 and 1799 (1832). 
rather additional argument of absence of authority? Is it not rather negation of creation of crime? How do these provisions affect and how are they affected by the First Amendment?

In the constitution we find certain powers delegated-their extent and their limitation. These powers necessarily carry with them all authority necessary or incident to their execution. Of the methods to be adopted in execution, Congress is the exclusive judge, if such execution falls at all within the power of Congress. The discretion of the general government, however, is conditioned ( $I$ ) that the means adopted be calculated to carry out some express power, (2) that they do not conflict with an undoubted power of the state to act, and (3) that they are not means prohibited by the constitution itself.

Treason has been construed to cover a multitude of things. Different governments call different acts an offense against sovereignty. Successive ages have produced different theories. An arbitrary government would make it all embracing; a mild government would be less harsh. A tyrannical government would condemn all who failed to agree with or who oppose its slightest wish or policy. Parties in power are always seeking and always will seek to perpetuate, enlarge and strengthen their hold on authority. And the term "treason" may be made as elastic as the desire of the dominant power.

Formerly, in England, it was a term of such latitude that the subject may be said to have held his life at the caprice of the ruling prince. In his Pleas of the Crozon, Lord Hale says:"

"At common law there was a great latitude used in raising offenses into the crime and punishment of treason, by way of interpretation and arbitrary contruction, which brought in great inconvenience and uncertainty." . . . Thus "accroaching of [i. e., encroaching on] royal power was a usual charge of treason anciently, tho' a very uncertain charge; that no man could tell what it was, nor what defense to make to it." ,

Later, after enumerating various instances, he says that

"by these, and the like instances, that might be given, it appears, how arbitrary and uncertain the law of treason was before the statute of $25 \mathrm{E}$. 3, whereby it came to pass, that almost every offense, that was, or seem'd to be a breach of the faith and alligeance due to the king, was by construction and consequence and interpretation, raised into the offense of high treason."

That statute was enacted to remedy that condition of affairs. Lord Coke says ${ }^{9}$ that

"therefore . . . this was called benedictum parliamentum, as it well deserved"; and the like honor was given to it by the different

'I Pleas of the Crown (Dublin, 1778) 79, 80.

s Ibid., 82.

'3 Coke, Inst. (London, I797) 2. 
statutes which from time to time brought back treason to its standards, "all agreeing in the magnifying and extolling of this blessed act."

Yet, despite this statute, in the words of Lord Hale, ${ }^{10}$

"things were so carried by parties and factions," in the succeeding reign of Richard II, "that this statute was little observed; but as this or the other party prevailed, so the crimes of high treason were in a manner arbitrarily imposed and adjudged, to the disadvantage of the party, that was intended to be suppressed," which, by various vicissitudes and revolutions, mischiefed all parties, first and last, and left a great unsettledness and uneasiness in the minds of the people and was one of the occasions of the unhappiness of that king.

All this mischief was produced by the statute of the 2I of Richard II, which enacted, "That every man that encompasseth or pursueth the death of the King, or to depose him, or to render up his homage liege, or he that raiseth people and rideth against the King, to make war within his realm, and of that be duly attainted and adjudged, . . . shall be adjudged a traitor, of high treason against the crown. . . .;

This was a great snare to the subject, insomuch that the statute, first of Henry IV, which repealed it, recited "that no man knew how he ought to behave, to do, to speak or say, for doubt of such pains of treason"; and therefore, wholly to remove the prejudice, which might come to the King's subjects, the statute first of Henry 4 , chap. Io, was made, which brought back treason to the standard of the 25 of Edw. the 3 rd.

This statute of Henry IV shared the same fate as its predecessors. New treasons were raised by construction. Judges were found; as they always will be found, so subservient to power that as soon as Parliament acted, the old evils were raised by judicial decision. Affairs came to such a pass that it was found necessary to enact in the time of Philip and Mary a new law repealing all prior laws on the subject excepting the statute of Edward III, denouncing judicial constructive treason in the severest terms and expressly limiting the offense to the very words of the statute;

"by which law," says Lord Coke,"11 "the safety both of the King and of the subject, and the preservation of the common-weale, were wisely and sufficiently provided for, in such certainty, as nihil relictum est arbitrio judicis." "This statute," he says again,"12 "excluded all implications or inferences whatsoever." The statute even provided for proof, "not upon conjecturall presumptions or inferences, or straines of wit, but upon good and sufficient proof ... note, the word is not (probably) for then commune argumentum might have served, but the word is [provably,] be attainted."

\footnotetext{
${ }^{10} \mathrm{Op}$. cit., $83,85,86$. [The editor has been unable to verify the portions of this quotation not enclosed in the marks.-Ev.]

"Op. cit., 23.

"Ibid., 24, 12 .
} 


\section{And so Lord Hale: $:^{13}$}

'Now, altho' the crime of high treason is the greatest crime against faith, duty and buman society, and brings with it the greatest and most fatal dangers to the government, peace, and happiness of a kingdom, or state, and therefore is deservedly branded with the highest ignominy, and subjected to the greatest penalties, that the law can inflict; yet . . . it appears, I. How necessary it was, that there should be some fixed, settled boundary for this great crime of treason, and of what great importance the statute of $25 \mathrm{E}$. 3. was, in order to that end. 2. How dangerous it is to depart from the letter of that statute, and to multiply and inhanse crimes into treason by ambiguous and general words, such as accroaching of royal pozver, subverting of fundamental lazes, and the like; and 3 . How dangerous it is by construction and analogy to make treasons where the letter of the law has not done it, for such a method admits of no limits or bounds, but runs as far and as wide as the wit and invention of accusers, and the odiousness and detestation of persons accused, will carry men."

Such is the emphasis placed on this subject by these great men. The struggle went on through the centuries. Time after time a complaisant judiciary raised offenses to the standard of treason and time after time the Parliament brought back the crime to that of the venerable statute of Edward III. And it was not until comparatively recent times that any reasonable degree of security was obtained and the law brought to the condition in which it now is in England. It was only a few years before our Constitution was adopted that Lord Erskine was able to say on the trial of Lord George Gordon:14

"In nothing, therefore, is the wisdom and justice of our laws so strongly and eminently manifested, as in the rigid, accurate, cautious, explicit, unequivocal definition of what shall constitute this high offense; for high treason consisting in the breach and dissolution of that allegiance which binds society together, if it were left ambiguous, uncertain or undefined, all the other laws for the personal security of the subject would be utterly useless; since this offense, which, from its nature is so capable of being created and judged of by rules of political expediency on the spur of the occasion, would be a rod at will to abuse the most virtuous members of the community, whenever virtue might become troublesome or obnoxious to a bad Government.

"Injuries to the persons and properties of our neighbors, considered as individuals, which are the subjects of all criminal prosecutions, are not only capable of greater precision, but the powers of the state can be but rarely interested in straining them beyond their legal interpretation; but if treason, where the government itself is directly offended, were left to the judgment of its ministers, without any boundaries,-nay, without the most broad, distinct and inviolable boundaries marked out by law, - there could be no public freedom, and the condition of an Englishman would be no better than a slave's at the foot of a sultan; since there is little difference whether a man

${ }^{13}$ Op. cit., 86.

"I Specthes of Thomas Lord Erskine (London, 1870) 58. 
dies by the stroke of a sabre, without the forms of trial, or by the most pompous ceremonies of justice, if the crime could be made at pleasure by the state to fit the fact that was to be tried."

From this history, thus briefly detailed, it is apparent that in England at the time of the Convention of 1787 , there had finally been evolved the doctrine that there was no such crime as constructive treason. Precedents in England as of a prior time are of no avail to us and throw no light upon the subject other than to show that the offense had had to be confined by the letter of the statute.

The story of this struggle was known to our fathers. They were particularly familiar with the then recent effects of the French Revolution upon the judicial mind of England. They had fresh in their memories the infamous State trials, many on the subject of "seditious libels." They knew human nature, and they knew that the only way to prevent repetition of such abuse of authority in this country in times of great excitement was to insert in the organic instrument of government an unalterable rule defining the offense and its limitations. They therefore inserted in the Constitution a provision covering the subject, wherein extreme care was taken to protect the individual. Madison says ${ }^{15}$ that:

"As treason may be committed against the United States, the authority of the United States ought to be enabled to punish it. But as newfangled and artificial treasons have been the great engines by which violent factions, the natural offspring of free government, have usually wreaked their alternate malignity on each other, the convention have, with great judgment, opposed a barrier to this peculiar danger, by inserting a constitutional definition of the crime, fixing the proof necessary for conviction of it, and restraining the Congress, even in punishing it, from extending the consequences of guilt beyond the person of its author."

The Constitution of the United States says that:

"Treason against the United States shall consist only of levying war against them or in adhering to their enemies, giving them aid and comfort. No person shall be convicted of treason unless on the testimony of two witnesses to the same overt act, or on confession in open court. The Congress shall have power to declare the punishment of treason, but no attainder of treason shall work corruption of blood or forfeiture except during the life of the person attainted."16

There is the definition of treason. There is the beginning and the end of the offense. There is the whole test as to what the crime is. Nothing is left to construction. ${ }^{17}$ Treason "shall consist only" of

\footnotetext{
${ }^{15}$ The Federalist, No. 42.

${ }^{16}$ Art. III.

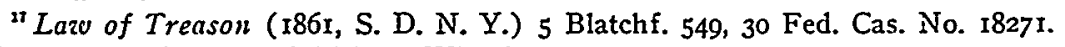
Druecker v. Salomon (I867) 2I Wis. 62.
} 
what is there stated. By the very fact of definition and of the use of the word "only," similar offenses by whatever title called are prohibited. ${ }^{18}$ The whole power of government in the matter therefore must be found in this provision. ${ }^{19}$ No matter what the supposed or actual necessity, the people have themselves determined that all possible offenses against sovereignty in this country are what is by the Constitution determined, and that no such offense shall be created unless therein clearly and unambiguously included. It is not a question of what powers other governments have, but of what the Constitution of the United States says. Generalizations as to sovereign power, necessity and the right of self preservation do not change or enlarge the rule. For those who adopted the Constitution limited the power and deemed all needful authority to be therein stated.

This definition refers, first, to levying war against the United States. War is defined as "an attempt by force, either to subjugate or overthrow the government against which it is levied."20 By this is not meant that there must be an intent to entirely subvert government; but it is sufficient if the object be to resist it in its sovereign capacity. ${ }^{21}$ If however it be merely for a local or private purpose and does not have a direct tendency, by a numerous force, to bring about a public purpose, there is no act of war. ${ }^{22}$ So also resistance to the execution of a law, even though accompanied by force, is not treason if for a private end. ${ }^{23}$ There must therefore be the intent to "overthrow government or compel it to yield through fear," and also an overt act. ${ }^{24}$ This overt act must be in itself "such as pertains to warlike

\footnotetext{
${ }_{18}$ 'The word 'only' was used to exclude from the criminal jurisprudence of the new republic the odious doctrine of constructive treason. Its use, however, while limiting the definition to plain overt acts, brings those acts into conspicuous relief as being always in essence treasonable." Shortridge $v$. Macon (1867, C. C. N. C.) 6I N. C. 392,22 Fed. Cas. No. 12812.

${ }^{11}$ See United States v. Greathouse (1863, N. D. Calif.) 4 Sawy. 457, 26 Fed. Cas. No. 15254; United States v. Hoxie (1808, D. Vt.) I Paine 265, 26 Fed. Cas. No. 15407; United States v. Fries (1799, D. Pa.) 3 Dall. 515, 9 Fed. Cas. No. 5 I26.

${ }^{20}$ Ex parte Bollman (1807, U. S.) 4 Cranch, 75.

${ }^{2}$ Law of .Treason (1842, D. R. I.) I Story, 614, 30 Fed. Cas. No. 18275.

${ }^{22}$ United States v. Hoxie (I808, D. Vt.) I Paine, 265, 26 Fed. Cas. No. 15407; Charge to Grand Jury (I861, D. Mass.) i Sprague, 602, 30 Fed. Cas. No. I8273; Charge to Grand Jury (1862, D. Mass.) 2 Sprague, 292, 30 Fed. Cas. No. 18274. [This has been the law; it would seem, however, that the anti-sedition bill now before the House contemplates a decided change in the definition of treason; and there may be question as to the constitutional validity of the proposed redefinition. See text of the Graham Bill, as given in the New York Times for Jan. 6, I920, pp. I-2.-ED.]

${ }^{23}$ United States v. Hanway (185I, E. D. Pa.) 2 Wall. Jr. I39, 26 Fed. Cas. No. 15299 .

${ }^{24}$ See United States v. Werner (I918, E. D. Pa.) 247 Fed. 708.
} 
operations." ${ }^{25}$ Words alone, written or spoken, could not fulfil the test. ${ }^{28}$

"To suffer the civil magistrate to intrude his powers into the field of opinion and to restrain the profession or propagation of principles on supposition of their ill tendency is a dangerous fallacy which at once destroys all liberty because being, of course, a judge of that tendency, he will make his opinions the rule of judgment and approve or condemn the sentiment of others only as they shall square with or differ from his own. It is time enough for the rightful purposes of civil government for its officers to interfere when the principles break out into overt acts against peace and good order."2i

Words may of course be used incidentally in making war; as where "printed in relation to an act or acts which if committed with a treasonable design, might constitute such overt act."2s But it is not the words that constitute the treason. ${ }^{29}$ It is the overt act done with the intent specified in the Constitution.

The definition goes on to speak of adhering to the enemy, giving them aid and comfort. "This merely affirms the common law doctrine of aider at the fact as applicable to the levying of war in treason." ${ }^{30}$ There must be all the elements specified in the definition. The fact that an enemy might be comforted by words written or spoken, without the overt act of giving aid to those making war, would not bring the act within the test of the Constitution. It is not meant that the mere giving of satisfaction would constitute giving aid and comfort. But it must be something done in furtherance of a hostile design. ${ }^{31}$ The act of a spy, for instance, in obtaining information and conveying it to hostile forces would be sufficient. He must necessarily use words. But the writing or the speaking does not in itself constitute the treason; it is the act of obtaining and conveying information which is made up in part of the writing and speaking.

Congress may declare war, provide for raising and supporting armies, for maintaining the navy, and make all laws necessary to

${ }_{25}^{25}$ Bishop, New Criminal Law (1892) sec. I231 (3).

${ }^{2}$ See Phipps v. United States (1918, C. C. A. 4th) 25I Fed. 879.

${ }^{27}$ Reynolds $v$. United States (1878) 98 U. S. I45.

${ }^{23}$ See United States v. Werner, supra, $7 \mathrm{II}$.

= Charge to Grand Jury (I861, S. D. Oh.) I Bond 609, 30 Fed. Cas. No. 18272. "Words, oral, written or printed, however treasonable, seditious or criminal, do not constitute an overt act of treason within the definition of the crime." Laze of Treason, Charge to Grand Jury, supra.

${ }^{30} 2$ Bishop, op. cit., sec. I227. "If the war be actually levied-that is, if a body of men be actually assembled for the purpose of effecting by force a treasonable purpose-all those who perform any part, however minute or however remote from the scene of action, and who are actually leagued in the general conspiracy, are to be deemed traitors." Ex parte Bollman, supra, 126; I Burr's Trial (ed. Comb) 322.

"Charge to Grand Jury, supra. 
carry into execution these express powers. It may regulate transportation, may even take over the food supply of the nation, may impress the body of the citizen for military service within the limitations of the provisions relating thereto-all under the so-called war power. But the means adopted must be immediately related to that end. And they must not be such as are prohibited. ${ }^{32}$

The war power is a power of vast extent, necessary for preservation of existence of government. But it is not unlimited. Arbitrary power does not exist in this country, and the war power, like every other delegation in the Constitution, is limited by that instrument.

"Those great and good men [the framers of the Constitution] saw that troublous times would arise, when rulers and people would become restive under restraint and seek by sharp and decisive measures to accomplish ends deemed just and proper, and that the principles of constitutional liberty would be in peril unless established by irrepealable law .. . The Constitution ..... is the law for rulers and people; equally in war and in peace, and covers with the shield of its protection all classes of men, at all times and under all circumstances. No doctrine involving more pernicious consequences was ever invented by the wit of man than that any of its provisions can be suspended during any of the great exigencies of government. Such a doctrine leads directly to anarchy or despotism, but the theory of necessity on which it is based is false; for government, within the Constitution, has all the powers granted to it, which are necessary to preserve its existence; as has been happily proved by the result of the great effort to throw off its just authority. . . .

"But it is said that the jurisdiction is complete under the laws and usages of war.

"It can serve no useful purpose to inquire what those laws and usages are, whence they originated, where found, and on whom they operated. They can never be applied to citizens in States which have upheld the authority of the government, and where the courts are open and their process unobstructed.

"When peace prevails and the authority of the Government is undisputed there is no difficulty of preserving the safeguards of liberty, for the ordinary modes of trials are never neglected and no one wishes it otherwise; but if society is disturbed by civil commotion-if the passions of men are aroused and the restraints of law weakened, if not disregarded-these safeguards need and should receive the watchful care of those entrusted with the guardianship of the Constitution and laws.

"In no other way can we transmit to posterity unimpaired the blessings of liberty consecrated by the sacrifices of the Revolution." ${ }^{\prime 3}$

\footnotetext{
${ }^{2}$ See Ex parte Milligan (1866, U. S.) 4 Wall. 2.

"Ex parte Milligan, supra; see also Johnsonv. Jones (I867) 44 I1l. 142, I65: "I heartily concur in the sentiment that the constitution of the United States was designed by its framers, and has hitherto been so understood by the people, to be the same protecting instrument in war and in peace; that a state of war does not enlarge the powers of any one department of Government established by it, nor has any one of these defendants the right to urge 'necessity' or 'extraordinary emergencies' as a plea for the usurpation of gowers not granted.
} 
Congress has of course the power to adopt any means consistent with the Constitution to render effective the authority in it vested. But the delegations and prohibitions of which it is composed all constitute one instrument which must be construed as a whole. It is not "self destructive" and every section must be deemed consistent with every other. ${ }^{34}$

It is to be noted that all authority relative to treason and to the conduct of war are found in the body of the Constitution. In the struggle for its adoption, strong opposition was manifested, and it is an historical fact that the consent of a sufficient number of states was secured upon condition that provision be immediately made for the protection of the person and property. Thereafter the first ten Amendments were proposed and adopted. The very first one was as to the freedom of speech and of the press.

Each contained a limitation of power. Each contained prohibitions express and emphatic, and placed barriers in the way of the use of means to be adopted in carrying out the authorizations contained in the original instrument. No matter what the necessity or supposed exigency, these things could not be done. ${ }^{35}$ The people acted and they were sovereign. They said that "Congress shall make no law respecting an establishment of religion, or prohibiting the free exercise thereof; or abridging the freedom of speech or of the press, or the right of the people peaceably to assemble, and to petition the government for the redress of grievances"; that "no soldier shall, in time of peace, be quartered in any house without the consent of the owner, nor in time of war, but in the manner prescribed by law"; that "the right of the people to keep and bear arms shall not be infringed"; that "unreasonable searches and seizures" were prohibited, and provision was made for cases where warrants were to be issued. Grand juries to indict were made mandatory. Double jeopardy was forbidden. No person could be compelled to be a witness against himself in any criminal case. Due process of law must be observed and compensation made for property taken for public use. A fair trial was secured, and trial by jury rendered inviolate. Bail must be reasonable and "no cruel and unusual punishment

The first is the tyrant's plea, and the other places the dearest rights of the citizen at the mercy of the dominant party, who have only to declare the 'emergency' which they can readily create pretexts for, which bad men are keen to find and eager to act upon. There can be, and there should be, no higher law for the conduct of the Government in its relation to the citizen than the Constitution of the United States."

"Billings v. United States (I914) 232 U. S. 26r, 282, 34 Sup. Ct. 421. "Neither the President nor Congress nor the judiciary can disturb any of the safeguards of civil liberty, except so far as the right is given to suspend in certain cases the privilege of the writ of habeas corpus." Ex parte Milligan, supra.

${ }^{85}$ United States $v$. Russell (1871, U. S.) 13 Wall. 623, 627-8. 
inflicted." Rights not delegated were reserved to the people and enumeration of rights in the Constitution "shall not be construed to deny or disparage others retained by the people."

These prohibitions, adopted subsequently to the Constitution, limit and circumscribe every power granted in that instrument. The end may be lawful. The Constitution may approve it. But that end may not be accomplished and that thing must not be done by any means included in these amendments or forbidden by any provision in the constitution.

The very first of these Amendments-first because deemed most important and most important because free institutions could not long endure if the citizen were not free to scrutinize and criticise acts of his representative in government and "seek redress of grievances," reads as follows:

"Congress shall make no law respecting the establishment of religion or prohibiting the free exercise thereof; or abridging the freedom of speech or of the press; or the right of the people peaceably to assemble and to petition the government for the redress of grievances."

"Congress shall make no law." It is an express mandatory prohibition, absolute in its terms. It shall make no law abridging the freedom of speech or of the press. It uses the same terms as to both free speech and a free press, and there is a precise denial of power to abridge either.

Remember, that before this Amendment was adopted, Congress had no power delegated to it in the premises. Remember that it was in order to avoid exercise of such power as an implied power or a power in aid of the express powers granted, that this Amendment was adopted. And the history of this country shows that this caution was grounded on the greatest wisdom.

It therefore appears that the so-called war power, and the authority in reference to treason, were not to constitute a modification of the right of free speech and a free press. On the contrary, not only was the definition of treason a limitation on the power of Congress, but the provisions of the Bill of Rights were, equally, express prohibitions on the power of government in carrying out the so-called war powers, in acting in reference to treason, and in carrying out each and every other grant of authority contained in the Constitution; and the United States has no authority whatsoever over the press or speech of the individual.

The "freedom of speech or of the press" was "sought to be secured. By these words are meant exactly what they signified at the common law-no more and no less. The terms had a definite, well defined scope. They stood for a certain idea.

"For these standards we must look to the common law rules which 
were in force when the constitutional guarantees were established, in reference to which they were adopted."36

These are matters of substantive law. They were matters of substantive law established at the time of the adoption of the Constitution. The common law prescribed the doctrine and its limitations. And inasmuch as there is no common law of the United States adopted for the federal government, ${ }^{37}$ it has no authority to enlarge or (aside from the effect of the First Amendment) circumscribe the extent of the right. The states undoubtedly, unless restrained by their own Constitution or that of the United States-a matter with which we are not here concerned-might change this branch of the law. It is within their reserved powers. But the federal government cannot.

Let us examine this common law rule. What restrictions do we find? What is the extent and the limitations of the doctrine? A man may speak and write what he will. That cannot be censored. But for the abuse of that right there are certain penalties. Even the meaning of "abuse" was clearly established and defined. He might be civilly and criminally liable for a libel; he might be civilly liable for a slander. The statement or writing may even be "privileged." Greater latitude is allowed in some cases than in others, as in criticism of candidates for office and public officials, or where a confidential relation exists, and the like. If he so speak or write as to create a condition that has a tendency to interfere with the orderly administration of justice, he may be punished as for a contempt-a matter within the inherent power of the courts themselves. A man may discuss public measures and events within certain limitations.

"It is very easy to lay down a rule for the discussion of constitutional questions; that they are privileged if conducted with calmness and temperance, and that they are not indictable unless they go beyond the bounds of free discussion. But what is calmness and temperance, and what is fair in the discussion of the supposed evils in the government? And if something is to be allowed 'for a little feeling in men's minds' (Regina v. Collins, 9 C. \& P. 456, 469, per Littledale, J.), how great shall the allowance be? The heat of the discussion will generally be in proportion to the magnitude of the evil as it appears to the party discussing it; must the question whether he has exceeded due bounds or not be tried by the judge or jury who may sit under different circumstances from those under which he has spoken, or at least after the heat of the occasion has passed away, and who, feeling none of the excitement themselves, may think it unreasonable

${ }^{20}$ Cooley, Constitutional Limitations (6th ed., 1890) 605; also pp. 598, 599, 602 and ch. Io generally. [This represents, in substance, the position of Justice Holmes' dissent in Abrams v. United States (1919) 40 Sup. Ct. 17, 20, decided since Mr. Hart's paper was written. As is pointed out in Comments (1920) 29 Yale LAw Journal, 337, Justice Holmes' position is thoroughly sound in law and in policy, and there is no expression in the majority opinion irreconcilable with his views. -ED.]

"United States $v$. Hudson (1812, U. S.) 7 Cranch, 32. 
that any one else may ever have felt it? The dangerous character of such prosecutions would be the more glaring if aimed at those classes who, not being admitted to a share in the government, attacked the constitution in the point which excluded them. Sharp criticism, ridicule and the exhibition of such feeling as a sense of injustice engenders, are to be expected from any discussion in those cases; but when the very classes who have established the exclusion as proper and reasonable are to try as judges and jurors the assaults made upon it, they will be very likely to enter upon the examination with a preconceived notion that such assaults upon their reasonable regulations must necessarily be unreasonable. If any such principle of repression should ever be recognized in the common law of America, it might reasonably be anticipated that in time of high party excitement, it would lead to prosecutions by the party, to bolster up wrongs and sustain abuses and oppressions by crushing adverse criticism and discussion. . . . The English common law rule which made libels on the constitution or the government indictable, as it was administered by the courts, seems to us unsuited to the condition and circumstances of the people of America, and therefore never to have been adopted by the people of the several States. If we are correct in this, it would not be in the power of State legislatures to pass laws which would make mere criticism of the constitution or of the measures of government a crime, however sharp, unreasonable and intemperate it might be. The constitutional freedom of speech and of the press must mean a freedom as broad as existed when the constitution which guarantees it, was adopted, and it must not be in the power of the legislature to restrict it, unless it might be in those cases of publications injurious to private character, or public morals or safety which came strictly within the reasons of civil and criminal liability at the common law, but in which, nevertheless, the common law as we adopted it failed to provide a remedy. . . . The constitutional provisions do not prevent modification of the common law rules of liability for libels and slanders, but they would not permit bringing new cases within those rules when they do not rest upon the same or similar reasons."38

The rules as to accessory before the fact were a part of the doctrine of freedom of speech and of the press. The First Amendment to the Constitution does not justify lawlessness. ${ }^{39}$

"The First Amendment, while prohibiting legislation against free speech as such, cannot have been and obviously was not intended to give immunity for every possible use of language. (Robertson $v$. Baldwin, I65 U. S. 275, 28I). We venture to believe that neither Hamilton nor Madison nor any other competent person then or later ever supposed that to make criminal the counselling of a murder within the jurisdiction of Congress would be an unconstitutional interference with free speech.",10

At the common law it was unlawful for one to advise or aid or abet another in the commission of crime. If therefore it is within the

\footnotetext{
${ }^{s 3}$ Cooley, op. cit., 6r3-615.

* United States v. Pierce (1917, N. D. N. Y.) 245 Fed. 878.

${ }^{2}$ Frohwerk v. United States (1919) 39 Sup. Ct. 249; see Debs v. United States (1919) 39 Sup. Ct. 251; United States v. Prieth (1918, D. N. J.) 251 Fed. 946.
} 
undoubted power of Congress to pass a law, it would be unlawful for anyone to advise or counsel or incite another to disobey that law..1 Nor would an Act of Congress so declaring be a law abridging the rights of free speech or a free press. ${ }^{42}$ On the contrary, it would be an act consistent with that right and therefore constitutional.

It is upon this ground that the courts have upheld the recent Espionage Act and Sedition Acts. ${ }^{43}$ In some of the cases involving these acts, we note the use of the words, "giving aid and comfort to the enemy." 41 In others, there are no such expressions. It is not meant by such expressions that the offense denounced is a species of treason. ${ }^{45}$ If it were, the decisions would be unsound, as there is no adhering to the enemy involved.

In some of the cases, there was a conspiracy to violate the law.40 This is, however, merely one phase of the doctrine. A conspiracy is not necessary. A single man may be an accessory before the fact. ${ }^{47}$

The "act" in question covers both the completed offense and an attempt to commit it. If the person actually cause violation of the law, he would be an accessory before the fact, no matter whether he foresaw the result or not.

"At common law, the utterer of written or spoken words is not liable merely because he knows they will reach those who will find in them the excuse for criminal acts. On the contrary, the rule has always been that to establish criminal responsibility, the words uttered must amount to counsel or advice or command to commit the forbidden acts and this is the classic form of expression. (4 Bl. Comm. $36,37$.$) Of course the counsel or advice need not be explicit since$ the meaning of words comprises what their hearers understand them to convey. 'Yet the terms 'counsel' or 'advice' have a content which can be determined objectively, and do not pend upon the subjective intent of their author." $\$ 8$

So also where the natural tendency of the words is to induce commission of crime, he would come within the prohibition even though it does not in fact so result.

"See United States ข. Nearing (I9I8, S. D. N. Y.) 252 Fed. 223; see Dall v. United States (1918, C. C. A. 8th) 253 Fed. 646; Masses Publishing Co. v. Patten (1917, S. D. N. Y.) 244 Fed. 535.

Frohwerk v. United.States, supra.

"Debs v. United States, supra; see Schenck v. United States (1919) 39 Sup. C.t. 25 I.

"United States v. Pierce, supra; United States v. Schulze (1918, S. D. Calif.)

253 Fed. 377; United States v. Schafer (1918, E. D. Pa.) 254 Fed. I35.

"Uitited States v. Frohwerk, supra.

"United States v. Pierce, supra; United States v. Prieth, supra; United States v. Frohwerk, supra.

"United States v. Scott Nearing, supra; United States v. Boutin (1918, N. D. N. Y.) 25I Fed. 313.

"United States v. Scott Nearing, supra, 227. 
"If the natural and reasonable effect of what is said is to encourage resistance to a law and the words are used in an endeavor to persuade to resistance, it is immaterial that the duty to resist is not mentioned, or that the interest of the person addressed is not suggested."49

For a man must be held as if he intended the natural consequences likely to follow from his word or act. ${ }^{50}$ It is therefore not necessary that anyone be in fact influenced..$^{51}$ If the words have a tendency to produce violation of law, it will be sufficient..2 ${ }^{52}$ But the tendency should be clear, and the danger imminent.

The question is "in every case whether the words are used in such circumstances and are of such a nature as to create a clear and present danger that they will bring about the substantive evils that Congress has a right to prevent."."53

If not so used, they do not come within the permitted inhibition. ${ }^{54}$ This however, is a question of fact. $^{55}$

These propositions are all part of the common law doctrine of free speech and free press, with which the First Amendment has no concern. The right of criticism or expression of opinion, either in language or by cartoon, however intemperate in tone or harmful in effect, even including the Conscription law, is not within the power of Congress to abridge, where such statements stop short of the limitation of the substantive law. ${ }^{56}$

"The purpose of the act (the Espionage Act), as we understand it, was not to repress legitimate criticism of Congress or of the officers of the government, or to prevent any proper discussion looking to the repeal of any legislation which may have been enacted."57

${ }^{2}$ Masses Publishing Co. v. Patten (Ig17, C. C. A. 2d) 246 Fed. 24, 38; see United States v. Prieth, supra.

${ }^{\text {so } U n i t e d ~ S t a t e s ~ v . ~ S c h u t t e ~(1918, ~ D . ~ N . ~ D .) ~} 252$ Fed. 212; United States $v$. Hall, supra; Debs v. United States, supra; see United States v. Schafer (1918, E. D. Pa.) 254 Fed. 135 .

${ }^{11}$ United States $v$. Kraft (rg18, C. C. A. 30) 249 Fed. 919; United States $v$. Werner (I918, E. D. Pa.) 247 Fed. 708; Doe v. United States (I918, C. C. A. 8th) 253 Fed. 903; see United States v. Demborvski (I918, E. D. Mich.) 252 Fed. 896 .

${ }^{52}$ Kirchner v. United States (1918, C. C. A. 4th) 255 Fed. 30r.

* Schenck v. United States (19r9) 39 Sup. Ct. 246; United States v. Eastman (1918, S. D. N. Y.) 252 Fed. 232; see United States v. Sugarman (1917, D. Minn.) 245 Fed. 604 ; see Deason v. United States (1918, C. C. A. 5th) 254 Fed. 259.

4 United States v. Pape (1918, S. D. I11.) 253 Fed. 270; United States v. Schaefer (1918, E. D. Pa.) 248 Fed. 290; United States v. Von Bank (19r8, C. C. A. 8th) 253 Fed. 641 .

${ }^{\infty}$ Reynolds v. United States, supra; United States v. Schafer, supra.

United States v. Hall (19I8, D. Mon.) 248 Fed. 150; Von Bank v. United States (1918, C. C. A. 8th) 253 Fed. 64I; see Masses Publishing Co. v. Patten, supra.

"Masses Publishing Co. v. Patten, supra; see United States v. Schutte 
In discussing this case of Masses Publishing Co. v. Patten, Judge Learned Hand says:

"In that case, it is true, there is language which, taken broadly, can be made to mean that the author is liable if he merely knows that his words will so result (cause insubordination or obstruct the draft). This, I can hardly think, can have been the significance of the decision, since, as I have already shown, the inevitable consequence would be to imperil any discussion of public matters. It certainly was not the purpose of that case to do so or indeed to insist that the style or manner of the discussion must measure with any standard of taste or temperance. Such a result would be foreign to the whole history of the subject. The test, as laid down in that-case, was, I think, this: That though in the forum of public discussion words which might not themselves amount to advice or counsel to violate the law, could nevertheless make their author criminally responsible if they were in fact the cause of the results forbidden, and if they were uttered with the specific intent of producing those results."'ss

"Every man has a right to any opinion that he may see fit to form about any proposed law or about any law that is on the statute books. Any man may do anything in itself legal to secure the repeal of any law in force. . . . He may make any argument that commends itself to his reason and judgment against the policy of any particular law, whether it be the law of the Selective Draft or any other. And he is not answerable for the wisdom of his arguments. He could not very well be put on trial even for the good faith of some of them. I am afraid if he could be, most of the political orators in every campaign would be liable for much they say about the other. party. We all of us say more against our political opponents than we really believe. But there is one limit. As long as the law is the law, it is the duty of every man to obey it, and he may not, under color or pretense of arguing against the wisdom of the law, or of advocating its repeal, do anything with intent to procure its violation."

"The evils to be prevented were not the censorship of the press merely, but any action of the government by means of which it might prevent free and general discussion of public matters as seem absolutely essential to prepare the people for an intelligent exercise of their rights as citizens.

"The constitutional liberty of speech and of the press as we understand it, implies a right to freely utter and publish whatever the citizen may please, and to be protected against any responsibility for so doing except so far as such publications, from their blasphemy, obscenity or scandalous character may be a public offense, or as by their falsehood and malice may injuriously affect the standing, reputation or pecuniary interests of individuals. Or, to state the same things in somewhat different words . . . we understand liberty of speech and of the press to imply not only liberty to publish but complete

(1918, D. N. D.) 252 Fed. 212, 214; see United States v. Hall, supra; see United States v. Mayer (Ig18, W. D. Ky.) 252 Fed. 868.

${ }^{*}$ United States $v$. Scott Nearing, supra. "We do not lose our right to condemn either measures or men because the country is at war." Frohwerk v. United States, supra.

${ }^{30}$ United States v. Baker (1917, D. Md.) 247 Fed. 124. 
immunity from legal censure and punishment for the publication, so long as it is not harmful in its character when tested by such standards as the law affords."

The Constitution did not extend the doctrine. Freedom of speech and of the press, as the term was understood at the common law, is what is referred to in the First Amendment; and that right to speak and write as limited by substantive law, "Congress shall make no law . . abridging."

"Whatever we have dared to think

That dare we also say.

We speak the truth, and what care we

For hissing and for scorn,

While some faint gleamings we can see

Of Freedom's coming morn."

${ }^{\infty}$ Cooley, op. cit., 604-5. 